\title{
NEW HOSTS OF MYROTHECIUM SPP. IN BRAZIL AND A PRELIMINARY IN VITRO ASSAY OF FUNGICIDES
}

\author{
${ }^{1}$ Quezado Duval, A.M.; ${ }^{1}$ Henz, G.P.; ${ }^{2}$ Paz-Lima, M.L.; ${ }^{3}$ Medeiros, A.R.; ${ }^{2}$ Miranda, B.E.C.; ${ }^{4}$ Pfenning, L.H.; ${ }^{1}$ Reis, A.* \\ ${ }^{1}$ Embrapa Hortaliças, Brasília, DF, Brasil; ${ }^{2}$ Universidade de Brasília, Departamento de Fitopatologia, Brasília, DF, Brasil; \\ ${ }^{3}$ Agência Nacional do Petróleo, Gás Natural e Biocombustíveis, Centro de Pesquisas e Análises Tecnológicas, Brasília, DF, Brasil; \\ ${ }^{4}$ Universidade Federal de Lavras, Departamento de Fitopatologia, Lavras, MG, Brasil.
}

Submitted: January 08, 2009; Returned to authors for corrections: July 08, 2009; Approved: August 28, 2009.

\begin{abstract}
Myrothecium roridum and $M$. verrucaria are two plant pathogenic species causing foliar spots in a large number of cultivated plants. This paper aims to study the causal agents of foliar spots in vegetable crops (sweet pepper, tomato and cucumber), ornamental plants (Spathiphyllum wallisii, Solidago canadensis, Anthurium andreanum, Dieffenbachia amoena) and a solanaceous weed plant (Nicandra physaloides). Most of the isolates were identified as M. roridum; only the isolate 'Myr-02' from S. canadensis was identified as $M$. verrucaria. All the isolates were pathogenic to their original plant hosts and also to some other plants. Some fungicides were tested in vitro against an isolate of M. roridum and the mycelial growth recorded after seven days. Fungicides with quartenary ammonium, tebuconazole and copper were highly effective in inhibiting the mycelial growth of $M$. roridum. This paper confirms the first record of $M$. roridum causing leaf spots in sweet pepper, tomato, Spathiphyllum, Anthurium, Dieffenbachia and N. physaloides in Brazil. We also report M. roridum as causal agent of cucumber fruit rot and M. verrucaria as a pathogen of tango plants.
\end{abstract}

Key words: Myrothecium roridum, $M$. verrucaria, vegetable crops, ornamentals, weeds, etiology.

\section{INTRODUCTION}

The genus Myrothecium was first described in the XVIII century, comprising three species. Tulloch (1972) (18) revised the genus and described eight species, two new species and three new combinations. Presently, there are several species of Myrothecium, most of them saprophytes. Only Myrothecium roridum Tode is considered an expressive plant pathogen (2). Besides this species, M. verrucaria (Alb. \& Schwein.) Ditmar is also regarded as a week plant pathogen. Myrothecium is a well supported sister group of Stachobotrys within the Hypocreales. Both groups share several morphological and biological characters, like formation of dark green conidia and are potentially mycotoxin producers. Supposedly, both genera represent a own family within Hypocreales (3). The species concept within the genus Myrothecium is rather broad, sometimes controversial and awaits revision.

Myrothecium roridum and $M$. verrucaria are ordinary soil fungi, and survive in this environment as saprophytes in decaying plant tissues $(4,5,16)$. Despite this saprophyte character, both species are able to cause diseases, mainly in the aerial parts of some plant species (5). In some plant species, $M$. roridum is seedborne and can be efficiently transmited by seeds (7). Field dissemination of these two fungal species occurs by splashes of rain water, irrigation or dew. Myrothecium is a facultative parasite with a large number 
of plant hosts, including vegetable crops, fruit plants and ornamentals $(8,11,18)$. Myrothecium roridum was reported as a pathogen of more than two hundred plant species belonging to distinct botanical families. In Brazil, M. roridum was reported in less than twelve plant hosts, such as peanut, soybeans, cotton, melon, Leucaena, sunflower, rice and common beans $(8,12,13)$. Another important species is $M$. verrucaria, also a facultative parasite, causing disease in a few economically important plant hosts when compared to $M$. roridum $(10,18)$. In Brazil, this species has been rarely found and was reported as a problem in tomato plants and associated to rice seeds (8).

Once in Brazil plant diseases caused by Myrothecium spp. are scarcely reported, there are no fungicides registered at the Ministry of Agriculture and Supply (Agrofithttp://extranet.agricultura.gov.br/agrofit_cons/principal_agrofit _cons). Besides, there are a few published papers worldwide on chemical control of this pathogen $(14,15)$. A preliminary test in vitro on the effect of some fungicides on the mycelial growth of Myrothecium can provide an useful information for future in vivo screenings and the registration of some fungicides.

During 2005, some samples of ornamental plants with leaf spots were received at the Laboratory of Plant Pathology of Embrapa Hortaliças (Embrapa Vegetable Crops) for regular diagnosis. Besides that, some samples of tomato, sweet pepper and Nicandra physaloides (L.) Pers leaves showing leaf spots similar of those caused by Myrothecium were collected in a vegetable grower area in Caxias do Sul county, State of Rio Grande do Sul, Brazil (Figure 1). This paper aims to clarify the etiology of leaf spots in some plants and evaluate the virulence of isolates of $M$. roridum and $M$. verrucaria. The effect of some fungicides on the mycelial growth of one isolate of $M$. roridum was evaluated in a preliminary study.

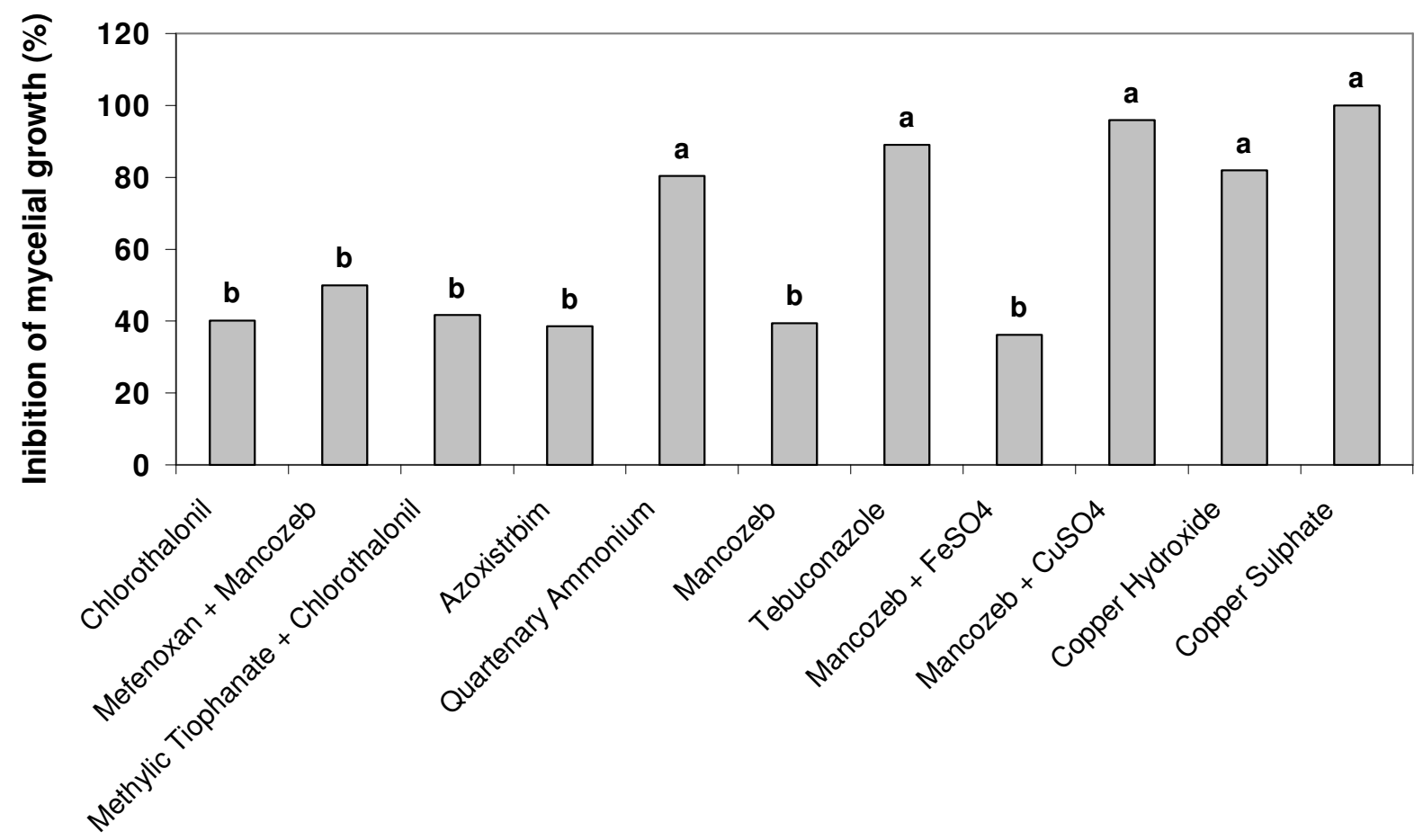

Fungicide

Figure 3. Inhibition of mycelial growth of Myrothecium roridum in PDA plates by fungicides [Media with the same letter do not differ by Tukey test $(5 \%)]$. 


\section{MATERIALS AND METHODS}

\section{Isolates of Myrothecium}

Eight isolates of Myrothecium were obtained from different plant hosts, received for diagnosis in the Laboratory of Plant Pathology at Embrapa Hortaliças (Table 1). Isolation was performed on PDA media with the addition of tetracycline antibiotics. All the isolates were sent to the Universidade Federal de Lavras for further identification of the species.

\section{Pathogenicity tests}

First, all the isolates were inoculated on their original plant hosts. Each of the eight plant host was grown in plastic pots with $2 \mathrm{~L}$ of a mixture of sterilized substrate composed by $1 / 3$ of soil, $1 / 3$ of carbonized rice hulls and $1 / 3$ of sand. For each plant host, eight pots were cultivated with one single plant in each. Inoculation was performed in two ways, with and without foliar wounds, each one with four replicates, by spraying a spore suspension ( 1 x $10^{5}$ conidia/ml). Wound inoculation was performed by the application of carborundum to the lower and intermediate leaves of each plant, a slight finger rubbing and the spraying of the spore suspension. For the non-wounded it was not used the carborundum. Evaluation was performed seven days after inoculation, checking for the presence of leaf spots similar of those observed in the original plant host.

\section{Identification of the isolates}

Isolates were identified at the Mycology Laboratory of Universidade Federal de Lavras, Lavras, Minas Gerais State, Brazil. Morphological characteristics of sporodochia, conidiophores, phyallides and conidia were recorded and 50 conidia of each isolate were measured (length and width). Results were compared to those of different species of Myrothecium already published $(5,6,18)$.

Table 1. List of Myrothecium isolates, place of origin and original plant host.

\begin{tabular}{lllll}
\hline Isolate & \multicolumn{1}{c}{ Host } & \multicolumn{1}{c}{ Place of Origin } & \multicolumn{1}{c}{$\begin{array}{c}\text { Conidia size } \\
\text { (lenght x width) }\end{array}$} & Identification \\
\hline Myr.01 & Spathiphyllum wallisii & Gama - DF & $4.9-7.6(6.8) \times 1.2-2.7(1.7)$ & M. roridum \\
Myr.02 & Solidago canadensis & Valparaíso - GO & $6.0-10.0(7.8) \times 2.0-4.5(3.1)$ & M. verrucaria \\
Myr.03 & Cucumis sativus & Tijucas - SC & $6.1-7.7(6.5) \times 1.3-2.8(1.8)$ & M. roridum \\
Myr.04 & Anthurium andreanum & Gama - DF & $5.2-7.8(6.9) \times 1.1-2.5(1.6)$ & M. roridum \\
Myr.05 & Solanum lycopersicum & Caxias do Sul - RS & $6.2-7.4(6.4) \times 1.6-2.9(2.3)$ & M. roridum \\
Myr.06 & Capsicum annuun & Caxias do Sul - RS & $5.9-7.4(6.8) \times 1.6-2.4(2.0)$ & M. roridum \\
Myr.07 & Dieffenbachia amoena & Gama - DF & $5.9-7.1(6.5) \times 1.8-2.7(2.3)$ & M. roridum \\
Myr.08 & Nicandra physaloides & Caxias do Sul - RS & $6.9-8.5(7.8) \times 1.8-3.8(2.7)$ & M. roridum \\
\hline
\end{tabular}

\section{Cross pathogenicity}

All isolates were inoculated in the following plant hosts: Spathiphyllum wallisii Regel cv. 'Vivaldi', Solidago canadensis L., Cucumis sativus L. cv. 'Caipira', Anthurium andraeanum Lind, tomato cv. 'Yuba', sweet pepper cv. 'Yollo Wonder', chili pepper cv. 'Criollo de Morellos', Nicandra physaloides, melon cv. 'Eldorado' and cv. 'Hales Best Jumbo', cotton cv. 'Pieroba', Zantedeschia aethiopica (L.) Spring, Heliconia rostrata Ruiz
\& Pavon and Dieffenbachia amoena Gentil (Table 2). The solanaceous weed $N$. physaloides was inoculated only with its own isolate because the seeds showed low germination. Inoculation was done in the same way as described for the pathogenicity test, with foliar wounds. Evaluation was performed by checking for the presence of leaf spots and the measure of lesion diameter. 
Table 2. Cross inoculation of Myrothecium isolates in their original hosts and other plant species.

\begin{tabular}{|c|c|c|c|c|c|c|c|c|}
\hline \multirow[b]{2}{*}{ Plant host } & \multicolumn{8}{|c|}{ Myrothecium isolates } \\
\hline & Myr.01 & Myr.02 & Myr.03 & Myr.04 & Myr.05 & Myr.06 & Myr.07 & Myr.08 \\
\hline Anthurium & ++ & - & + & + & ++ & ++ & + & ++ \\
\hline Dieffenbachia & ++ & + & ++ & ++ & + & ++ & ++ & ++ \\
\hline Nicandra physaloides & NI & NI & NI & NI & NI & NI & NI & ++ \\
\hline Cucumber & ++ & ++ & ++ & ++ & ++ & ++ & ++ & ++ \\
\hline Chili pepper & ++ & + & + & ++ & ++ & + & + & ++ \\
\hline Sweet pepper & + & + & + & + & ++ & ++ & + & ++ \\
\hline Spathiphyllum & ++ & + & ++ & ++ & ++ & ++ & ++ & + \\
\hline Solidago canadensis & - & + & - & + & - & - & - & - \\
\hline Tomato & ++ & ++ & ++ & ++ & ++ & ++ & ++ & ++ \\
\hline Cotton & ++ & ++ & + & + & ++ & ++ & + & + \\
\hline Zantedeschia & + & - & + & ++ & ++ & ++ & ++ & NI \\
\hline Heliconia & + & + & ++ & ++ & + & + & ++ & + \\
\hline Melon cv. Eldorado & + & + & ++ & ++ & ++ & NI & ++ & + \\
\hline Melon cv. Hales Best Jumbo & ++ & + & + & ++ & + & + & + & + \\
\hline
\end{tabular}

(-) Symptomless; (+) Symptoms + mycelium; (++) Symptoms + sporodochia.

(NI) Non inoculated.

\section{Preliminary test of fungicides in vitro}

One isolate of Myrothecium ('Myr.01') was evaluated for its in vitro sensitivity to the following active ingredients of fungicides, on laboratory conditions: Daconil (clorothalonil), Ridomil Gold (mefenoxan + mancozeb), Cerconil (chlorotahalonil + methylic thiophanate), Amistar (azoxistrobim), Fegatex (quartenary ammonium), Manzate (mancozeb), Folicur (tebuconazole), Manzate + iron sulphate (mancozeb + iron sulphate), Manzate + copper sulphate (mancozeb + copper sulphate), Kocide (copper hydroxide) and copper sulfate, with the dosages recommended to tomato crop by the Agrofit system (Agrofithttp://extranet.agricultura.gov.br/agrofit_cons/ principal_agrofit_cons). Fungicides were diluted in sterilized water and later added to melting PDA media at the recommended doses in Petri dishes. Mycelia disks of $12 \mathrm{~cm}$ of diameter of Myrothecium isolates, grown during 10 days, were transferred to the center of the PDA plates. The plates were kept to a growth chamber at $25^{\circ} \mathrm{C}$ and $12 \mathrm{~h}$ of light for seven days. For each isolate four replicates were used and the check treatment was plates with the mycelia disk without fungicide. Evaluation was done after 7 days by measuring the two opposite diameters of the fungi colony in all treatments and compared to the check treatment mycelial growth. With these two records, the inhibition of mycelial growth by the fungicides was calculated.

\section{RESULTS AND DISCUSSION}

Eight isolates showing whitish mycelia were obtained from the plant samples with leaf spots. After a while, some light-green points were noticed on the Petri plates turning to dark-green and black after some days. By using a sterioscope, those points were later on recognized as typical structures of sporodochia that measured up to $1.5 \mathrm{~mm}$ in diameter. Phyallides were $8.9-12 \times 1.2-2.3 \mu \mathrm{m}$. Conidia measured $6-8 \times 1.5-2.5 \mu \mathrm{m}$, with cylinder shape, and seven out of eight isolates showed conidia with round ends (Figure 2). Conidia color ranged from 
hyaline to light-green and the conidia mass was green to black. Myrothecium isolate 'Myr02' had rugose walls, conidia measuring 6-10 x 2-4,5 $\mu \mathrm{m}$, cylinder shape to lemonshaped or ellipsoidal, smooth, protuberant in the top and truncated in the bottom (Table 1). These characteristics are in accordance to those described in the literature for $M$. roridum (seven isolates) and $M$. verrucaria (isolate 'Myr02') $(5,6,18)$.

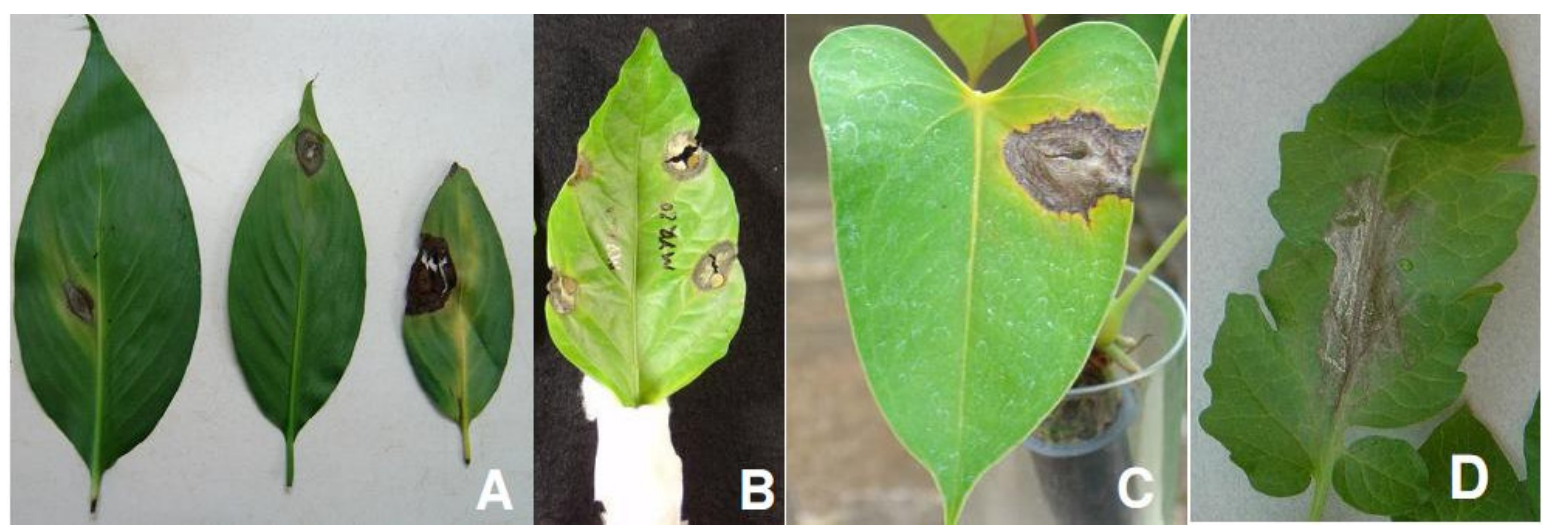

Figure 1. Leaf spots caused by Myrothecium roridum on Spathiphyllum wallisii (A), sweet pepper (B), Anthurium andreanum (C), and tomato (D).

In the pathogenicity trial, all isolates were virulent to their original host only when inoculated through foliar wounds caused by carburundum. Most of the isolates caused few foliar spots when inoculated without wounds and some were avirulent. The $M$. verrucaria isolate was low aggressive on its original plant host Solidago canadensis (Table 2), also infected in the same way by another isolate (Myr.04). The $M$. verrucaria isolate was also aggressive on cucumber, tomato and cotton, but less aggressive on sweet pepper, chili pepper, Spathiphyllum, Dieffenbachia, Solidago, Heliconia, and the two melon cultivars, and avirulent to Anthurium and Zantedeschia. The isolate 'Myr.04' infected all inoculated plants and was highly aggressive on most of them, excepted sweet pepper, cotton and Anthurium. Among all the plant hosts tested, cucumber and tomato were regarded as highly susceptible to all isolates.

In all the cases where the isolates were highly aggressive on the plant hosts, it was observed the development of large, concentric lesions. Those lesions, when observed with the aid of a stereoscopic microscope, showed a large number of sporodochia, sometimes visible with bare eye, concentrated mainly on the edge of the lesions. In some cases, the development of large necrotic lesions is correlated to the ability of producing toxins by the pathogen (9). Necrotrophic pathogens produce toxins that are released inside the host tissues and after it dies, so the pathogen can colonize them (9, 11).

Isolates of $M$. roridum showed great variability in their virulence, but all were highly aggressive on tomato and cucumber. This variability in virulence agreed to those observed by Taneja et al. (1990) (17). Results described in other publications clearly demonstrated the virulence of $M$. roridum on a large number of plant hosts worldwide $(5,6,18)$ as well as in Brazil $(7,8,12,13,14)$. Based on the pathogenicity on distinct plant hosts, Taneja et al. (1990) (17) suggest the presence of different pathotypes among $M$. roridum.

Fungicides inhibited the mycelial growth of isolate 'Myr.01' in two classes: highly effective and effective (Figure 3). Fungicides quartenary ammonium, tebuconazole, mancozeb + copper sulphate, copper hydroxide and copper sulphate were rated as highly effective. All fungicides with copper sulphate, alone or in a mixture, were effective in inhibiting the mycelial growth. Fungicides with broad spectrum of activity, such as 
chlorothalonil, mancozeb and methylic thiophanate + chlorothalonil were considered only effective in the inhibition of the mycelial growth of $M$. roridum. Those findings disagree with those obtained by Silva et al. (2006) (14) who observed that chlorotalonil and methylic thiophanate were respectively highly effective and effective on the inhibition of the mycelial growth of two isolates of $M$. roridum. In the same paper, the fungicide azoxtrobin was considered as non efficient.

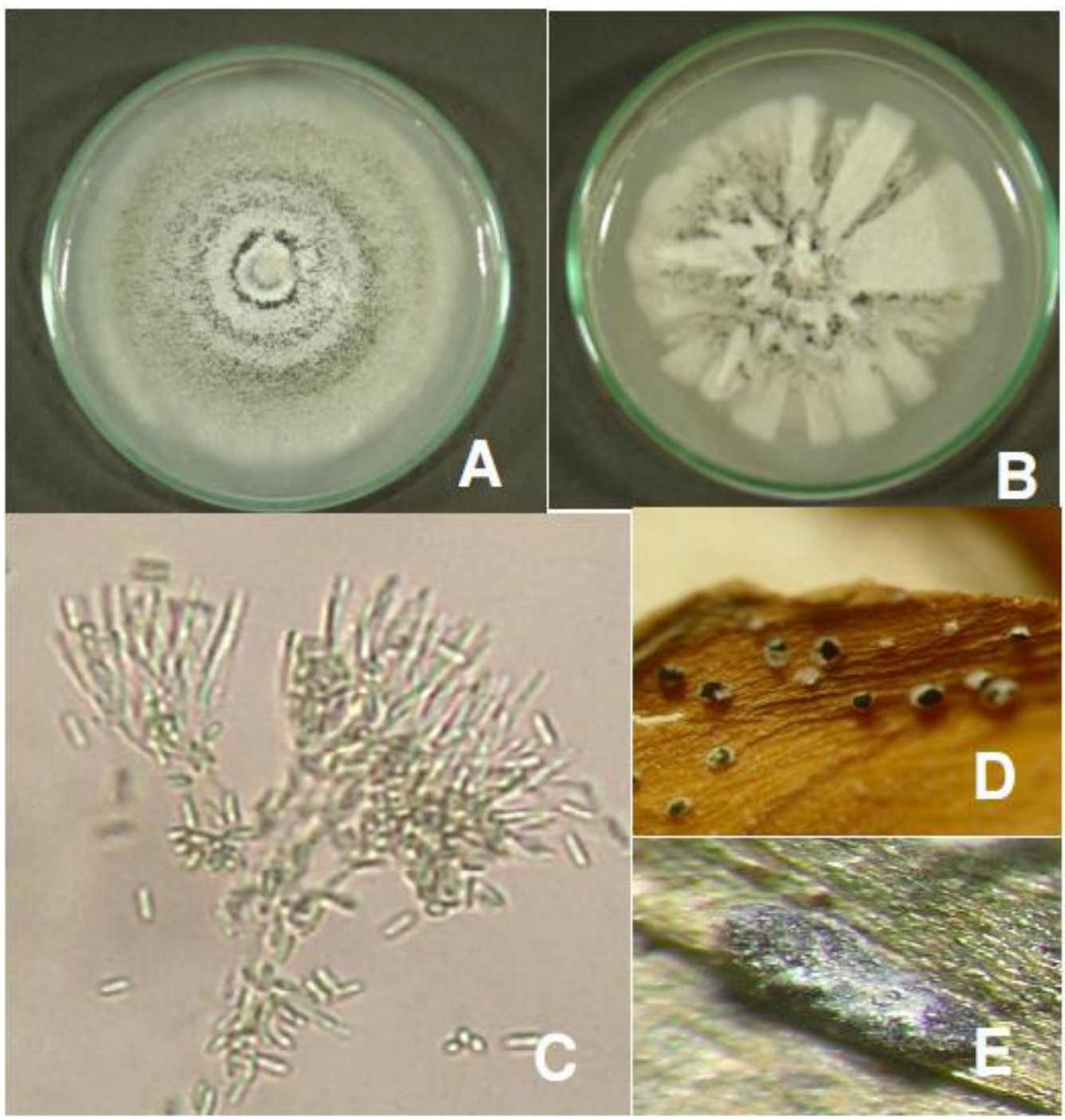

Figure 2. Reproductive structures of Myrothecium: (A) and (B) growth patterns on PDA of M. roridum (Myr.01) e M. verrucaria (Myr.02); (C) conidia and conidiophores of M. roridum (400X) and (D) and (E) sporodochia of de M. roridum (Myr.01), (5 e and $50 \mathrm{X})$.

This paper reports for the first time in Brazil the occurrence of M. roridum causing leaf spots on S. wallisii, $S$. canadensis, A. andraeanum, tomato, sweet-pepper, D. amoena and $N$. physaloides. It also reports $M$. verrucaria causing stem rot in $S$. canadensis and $M$. roridum causing fruit rot on cucumber. Fungicides quartenary ammonium, tebuconazole, and copper based products were highly effective in inhibiting the mycelial growth of one isolate of $M$. roridum. 


\section{REFERENCES}

1. Almeida, A.M.R.; Saraiva, O.F.; Farias, J.R.B.; Gaudêncio, C.A.; Torres, E. (2001). Survival of pathogens on soybean debris under no-tillage and conventional tillage systems. Pesq. Agropec. Bras. 36 (10), 1231-1238.

2. Ahrazem, O.; Gómez-Miranda, A.P.; Bernabé, M.; Leal, J.A. (2000). Heterogeneity of the genus Myrothecium as revealed by cell wall polysacharides. Arch. Microbiol. 173, 296-302.

3. Castlebury, L.A.; Rossman, A.Y.; Sung, G.H.; Hyten, A.S.; Spatafora, J.W. (2004). Multigene phylogeny reveals new lineage for Stachybotrys chartarum, the indoor air fungus. Mycol. Res. 108 (8), 864-872.

4. Costa, I.; Wanderley, P.M.; Cavalcante, M.A.; Fernandes, M.J.; Lima, D.M.M. (2006). Hyphomycetes from soil of an area affected by copper mining activities in the State of Bahia, Brazil. Braz. J. Microbiol. 37 (3), 290-295.

5. Domsch, K.H.; Gams, W.; Anderson, T. (2007). Compendium of soil fungi. 2nd Edition. IHW Verlag. Eching, Germany. 672 pp.

6. Ellis, M.B. (1971). Dematiaceous Hyphomycetes. CMI, Kew. 608 pp.

7. Gazzoni, D.L.; Yorinory, J.T. (1996). Manual de identificação de pragas e doenças da soja. Brasilia: Embrapa SPI. 128 pp.

8. Mendes, M.A.S.; Silva, V.L.; Dianese, J.C.; Ferreira, M.A.S.V.; Santos, C.E.N.; Gomes Neto, E.; Urben, A.F.; Castro, C. (1998). Fungos em Plantas no Brasil. Brasília: Embrapa Cenargen, 569 pp.

9. Murakami, R.; Yasui, H.; Shirata, A., Kato, A. (1999). Production of myrotoxin B by Myrothecium roridum isolated from Myrothecium leaf spot of mulberry in Japan. J. Sericult. Sci. Japan 68, 469-477.
10. Murakami, R.; Kobayashi, T.; Takahashi, K. (2005). Myrothecium leaf spot of mulberry caused by Myrothecium verrucaria. J. Gen. Plant Pathol. 71, 153-155.

11. Murakami, R.; Shirata, A. (2005). Myrotoxin B detection from mulberry leaves infected with Myrothecium roridum, cause Myrothecium leaf spot of mulberry, and possible roles in pathogenicity. Japan. J. Phytopath. 71, 91-100.

12. Poltronieri, L.S.; Duarte, M.L.R.; Alfenas, A.C.; Trindade, D.R.; Albuquerque, F.C. (2003). Three new pathogens infecting antilles cherry in the State of Pará. Fitopatol. Bras. 28 (4), 424-426.

13. Silva, J.C.; Meyer, M.C. (2006). Mancha de mirotécio 1 em algodoeiro causada por Myrothecium roridum. Summa Phytopathol. 32 (4), 390-393.

14. Silva, J.C.; Meyer, M.C.; Coutinho, W.M.; Suassuna, N.D. (2006). Fungitoxicidade de grupos químicos sobre Myrothecium roridum in vitro e sobre a mancha-de-mirotécio em algodoeiro. Pesq. Agropec. Bras. 41 (5), 755-761.

15. Singh, S.N. (1998). Efficacy of different fungicides against three different isolates of Myrothecium roridum. Ind. J. Plant Prot. 26, 72-74.

16. Souza-Motta, C.M.; Cavalcanti, M.A.Q.; Fernandes, M.J.S.; Lima, D.M.M.; Coimbra, J.P.; Laranjeira, D. (2003). Identification and characterization of filamentous fungi isolated from the sunflower (Helianthus annus L.) rhizosphere according to their capacity to hydrolyse inulina. Braz. J. Microbiol. 34 (3), 273-280.

17. Taneja, N.K.; Raj, S.; Seth, P.K. (1990). Existence of pathotypes in Myrothecium roridum. Ind. Phytopath. 43, 464-466.

18. Tulloch, M. (1972). The genus Myrothecium. Mycological Papers. (IMI) 130, 44 pp. 